\title{
ANALISIS JENIS PERTANYAAN YANG DIAJUKAN MAHASISWA MAGANG DI SMA KOTA SUKABUMI BERDASARKAN TAKSONOMI BLOOM REVISI PADA KONSEP PENCEMARAN LINGKUNGAN
}

\author{
Teguh Rachmatuloh Effendi ${ }^{1}$, Suhendar ${ }^{2}$, \& Aa Juhanda ${ }^{3}$ \\ ${ }^{1}$ Mahasiswa, ${ }^{2,3}$ Dosen Pendidikan Biologi FKIP Universitas Muhammadiyah \\ Sukabumi \\ J1. R. Syamsudin, S.H, No. 50, Kota Sukabumi \\ Email: teguhrachamtuloheffendi@gmail.com
}

\begin{abstract}
ABSTRAK
Penelitian ini bertujuan untuk menganalisis kemunculan jenis pertanyaan yang diajukan mahasiswa magang di SMA Kota Sukabumi berdasarkan taksonomi bloom revisi pada konsep pencemaran lingungan. Objek penelitian adalah tigaorang calon guru biologi yang mengajar di sejumlah SMA Kota Sukabumi Hasil penelitian menunjukan bahwa persentase jenis pertanyaan yang diajukan mahasiswa magang atau dari tiga calon guru rata-rata menggunakan pertanyaan tingkat rendah (Lower-Order Thinking Skills) yaitu pada mahasiswa magang ke satu pada aspek kognitif $\mathrm{C} 1$ faktual $16,66 \%$ dan $\mathrm{C} 1$ konseptual 16,66\%, sedangkan aspek kognitif C2 konseptual 50\%, dan aspek kognitif C3 prosedural $16,66 \%$. Pada hasil persentase jenis pertanyaan mahasisswa magang ke dua pada aspek kognitif $\mathrm{C} 1$ dan aspek pengetahuan faktual 28,57\%, C1 konseptual 14,28\%, dan C2 faktual 14,28\%, C2 konseptual 42,85\%, kemudian persentase pertanyaan tingkat tinggi pada aspek kognitif C6 dan aspek pengetahuan konseptual 14,28\%. Lalu pada hasil persentase mahasiswa ke tiga menunjukan aspek kognitif $\mathrm{C} 1$ faktual 42,85\%,C1 konseptual 14,28\%. Aspek kognitif C2 konseptual 14,28\%, sedangkan aspek kognitif C5 prosedural 14,28\%. Rata-rata persentase kemunculan jenis pertanyaan yang diajukan mahasiswa magang masih tergolong menggunakan pertanyaan tingkat rendah yaitu dari C1sampai C3 meskipun dari hasil penelitian menunjukan ada kemunculan meggunakan pertanyaan tingkat tinggi.
\end{abstract}

Kata Kunci: Jenis Pertanyaan, Mahasiswa Magang, Taksonomi Bloom Revisi 


\begin{abstract}
This study aims to analyze the emergence of the type of questions a student internship at SMA Sukabumi is the bloom taxonomic revision based on the concept of the environmental pollution. The object of research is the three candidates for a biology teacher who taught at a number of Sukabumi. The results showed that the percentage of questions a student internship or three prospective teachers use an average low-level questions(Lower order Thinking Skills)is on student interns to one on cognitive aspects factual C1 C1 conceptual 16.66\% and $16.66 \%$, while the cognitive aspects of the conceptual $50 \% \mathrm{C2}, \mathrm{C} 3$ and cognitive aspects of procedural $16.66 \%$. On the results of the percentage of questions a student internship to two on cognitive aspects and aspects of factual knowledge C1 28.57\%, 14.28\% conceptual C1, and C2 factual 14.28\%, 42.85\% conceptual $C 2$, then the percentage of high-level questions on C6 cognitive aspect and the aspect of conceptual knowledge $14.28 \%$. Then on the results show the percentage of students into three cognitive aspects C1 factual 42.85\%, 14.28\% conceptual C1. C2 conceptual cognitive aspects $14.28 \%$, while the cognitive aspects of procedural C5 $14.28 \%$. On average the percentage of types of questions a student internship still classified using low-level question is from C1 up to C3 although the results of research showed that there was the appearance of a high-level inquiry receipts.
\end{abstract}

Keywords: high school interns Student, Type of Question, A Revision Of Bloom's Taxonomy

\title{
PENDAHULUAN
}

Mahasiswa merupakan insan-insan calon sarjana yang terlibat dalam suatu intansi perguruan tinggi yang perlu dididik serta di harapkan dapat menjadi calon-calon intelektual. Mahasiswa diharapkan menjadi daya penggerak yang dinamis bagi proses moderenisasi dalam kehidupan masyarakat, dan mahasiswa diharapkan masuk dalam dunia kerja sebagai tenaga yang berkualitas serta profesional. Sarwono (1978) mengungkapkan Bahwa, mahasiswa merupakan calon intelek atau cendekiawan muda dalam suatu lapisan masyarakat yang sering kali syarat dengan berbagi predikat. Karena itu mahasiswa sebagai calon tenaga kerja harus sudah mempunyai wawasan dan keterampilan yang berkualitas dalam profesi yang diminatinya, contoh menjadi seorang pendidik atau guru harus sudah sangat piawai dalam mengelola kelas, mendidik, dan menerapkan metode-metode mengajar kepada siswa. 
Guru ialah pendidik profesional dengan tugas utama mendidik, mengajar, membimbing, mengarahkan, melatih, menilai, dan mengevaluasi siswa pada pendidikan anak usia dini di jalur pendidikan formal, pendidikan dasar, dan pendidikan menengah (Pasal 1 ayat 1 UU No. 14 tahun 2005 tentang Guru dan Dosen). Sardiman (2001) menyatakan bahwa guru adalah seseorang yang berwenang dan bertanggung jawab terhadap pendidikan murid-murid, baik secara individual maupun secara klasikal, baik di sekolah maupun di luar sekolah. Ahmadi (1977)mengungkapkan bahwa pendidik ataupun guru ialah sosok yang berperan sebagai pembimbing dalam proses belajar mengajar. Dengan itu guru dapat menghadirkan kondisi dan situasi proses kegiatan belajar mengajar yang dapat menumbuhkan dan membangkitkan semangat siswa sehingga siswa mampu menyadari kecakapan dan peluang prestasi yang mungkin didapatkannya.

Bertanya atau mengajukan pertanyaan merupakan salah satu tujuan penting bagi manusia yang harus hidup bersosial dengan lingkungannya. Bertanya merupakan ucapan verbal yang meminta jawaban dari seseorang/timbal balik dari seseorang yang bertanya. Pentingnya seorang guru/calon guru dalam pembelajaran mempunyai kriteria tertentu yaitu, memiliki keterampilan bertanya terhadap siswa, dapat mempraktekkan model-model yang terbaru, dapat menguasai kelas (interaksi) dan wacana pedagogik. Tetapi peneliti akan meneliti seorang mahasiswa magang (calon guru) biologi disekolah menengah atas yang mempunyai kriteria tentang pola keterampilan bertanya dengan muridnya. Pola keterampilan ini sangat penting sekali dalam proses pembelajaran, karena dapat meningkatkan pemahaman siswa terhadap materi yang akan dipelajari ataupun yang sudah dipelajari. Mauigoa dan Tekene (2006) menyatakan bahwa keterampilan bertanya tersebut berkaitan dengan keterampilan dasar mengajar. Hal itu mengindikasikan bahwa keterampilan dasar mengajar berperan penting dalam profesi guru ketika mengajar. Oleh karena itu proses belajar mengajar merupakan suatu proses yang mengandung serangkaian perbuatan guru dan siswa atas dasar hubungan timbal balik yang berlangsung dalam situasi edukasi untuk mencapai tujuan tertentu dalam pembelajaran. 
Interaksi atau hubungan timbal balik antara guru dan siswa merupakan syarat utama bagi berlangsungnya proses pembelajaran, proses belajar mengajar dikatakan baik dan tercapai apabila proses tersebut dapat menumbuhkan serta membangkitkan siswa dalam kegiatan belajar yang efektif, sehingga dapat memperoleh hasil yang baik dan maksimal.Dalam hal ini salah satu strategi pembelajaran dalam memfasilitasi dan membantu siswa, guru harus menguasai dan membekali diri dengan berbagai keterampilan dasar mengajar salah satunya keterampilan bertanya dalam kegiatan pembelajaran. Nasution (2009) berpendapat keterampilan bertanya merupakan suatu pengajaran itu sendiri, sebab pada umumnya guru dalam pengajaranya selalu melibatkan menggunakan tanya jawab. Ketrampilan bertanya merupakan keterampilan yang digunakan untuk mendapatkan jawaban/timbal balikan dari orang lain, hampir semua guru proses evaluasi, pengukuran, penilaian, dan pengujian dilakukan melalui pertanyaan. Sofa (2008) berpendapat bahwa keterampilan bertanya merupakan bagian yang tidak terpisahkan dalam rangka meningkatkan kualitas proses dan hasil pembelajaran yang sekaligus merupakan bagian dari keberhasilan dalam pengelolaan instruksional dan pengelolaan kelas. Melalui keterampilan bertanya guru mampu mendeteksi hambatan proses berpikir di kalangan siswa dan sekaligus dapat memperbaiki dan meningkatkan proses belajar di kalangan siswa. Bahwa keterampilan bertanya suatu bagian yang dapat meningkatkan kualitas siswa pada proses dan hasil belajar di sekolah, pada proses keterampilan bertanya guru mampu mengetahui kekurangan siswa dalam belajar dan keterampilan bertanyapun mampu meningkatkan siswa dalam proses pembelajaran siswa dikelas. Dengan itu pun calon guru/guru dapat mengelola kelas dengan efektif.

Pertanyaan-pertanyaan terkait proses kognitif Bloom (1956). Berdsarkan kognitif dalam versi taksonomi Bloom revisi Anderseon (2001) berpendapat, dilakukan pemisahan antara dimensi pengetahuan (knowledge) dan dimensi proses kognitif. Dimensi pengetahuan mencakup pengetahuan faktual, pengetahuan konseptual, pengetahuan prosedural dan pengetahuan metakognitif. Sedangkan pada dimensi kognitif meliputi C1 (menyebutkan), C2 (memahami0, 
C3 (mengaplikasikan), C4 (menganalisis), C5 ( mengevaluasi), dan C6 (mencipta).

Penelitian ini mengambil konsep yang digunakan mahasiswa magang (calon guru) biologi yang mengajar pada materi pencemaran lingkungan. Peneliti memilih materi pencemaran lingkungan diharapkan mahasiswa magang mampu meningkatkan pengetahuan kognitif siswa karena dengan menggunakan konsep materi pencemaran lingkungan ini sangat banyak sekali pertanyaanpertanyaan yang dapat diajukan mahasiswa magang kepada siswa untuk mengathui pengetahuan kognitif siswa dan meningkatkan pemahaman berdasarkan kejadian sehari-hari.

\section{METODE PENELITIAN}

Metode yang digunakan peneliti yaitu metode deskriptif. Objek penelitian adalah tiga mahasiswa magang atau calon guru biologi di sejumlah SMA Kota Sukabumi meliputi SMA Negeri 2 Kota Sukabumi, SMA Negeri 3 Kota Sukabumi dan SMA Negeri 4 Kota Sukabumi. Instrumen yang digunakan peniliti ialah menggunakan format lembar observasi pertanyaan mahasiswa magang.

1. Format Lembar Observasi Pertanyaan mahasiswa magang

Lembar observasi digunakan untuk mencatat serta menganalisis pertanyaan mahasiswa magang berdasarkan Taksonomi Bloom Revisi yaitu aspek kognitif (C1 mengingat, C2 memahami, C3 mengaplikasikan, C4 menganalisis, C5 mengevaluasi, dan C6 mencipta) dan dimensi pengetahuan (faktual, konseptual, prosedural, dan metakognitif) terhadap mahasiswa magang dikelas dalam mengajukan pertanyaan pada proses pembelajaran materi pencemaran lingkungan. Instrumen yang digunakan berupa mencatat pertanyaan-pertanyaan yang diajukan guru, yaitu suatu daftar yang berisi hal-hal yang akan diteliti. sehingga observer hanya mendeskripsikan dan menuliskan pada daftar tersebut.

Data yang diperoleh kemudian diolah dengan menggunakan rumus persentase Arikunto (2013)

$$
\% \text { kemunculan }=\frac{\sum \text { kemunculan jenis pertanyaan }}{\text { Jumlah pertanyaan }} \times 100 \%
$$


Nilai persentase kemunculan kemudian di dikelompokkan berdasarkan kategori sebagai berikut persentase $81-100 \%$ dikategorikan dengan predikat Baik Sekali $61-80 \%$ (Baik) $41-60 \%$ (Cukup) $21-40 \%$ (Kurang) dan persentase $\leq 21 \%$ dikategorikan sebagai kurang sekali (Arikunto, 2008).

\section{HASIL DAN PEMBAHASAN}

Pada penelitian ini, dasar untuk mengetahui jenis pertanyaan yang diajukan mahasiswa magang di SMA Kota Sukabumi berdasarkan Taksonomi Blom Revisi pada konsep pencemaran lingkungan yaitu melalui proses pembelajaran di kelas, maka dari itu metode inilah yang digunakan untuk analaisis jenis pertanyaan tersebut.

Berdasarkan analisis dan hasil observasi kemunculan jenis pertanyaan berdasarkan taksonomi bloom revisi pada konsep pencemaran lingkungan, pada setiap mahasiswa magang akan dibahas lebih jelas dalam bentuk grafik seperti Gambar 1.

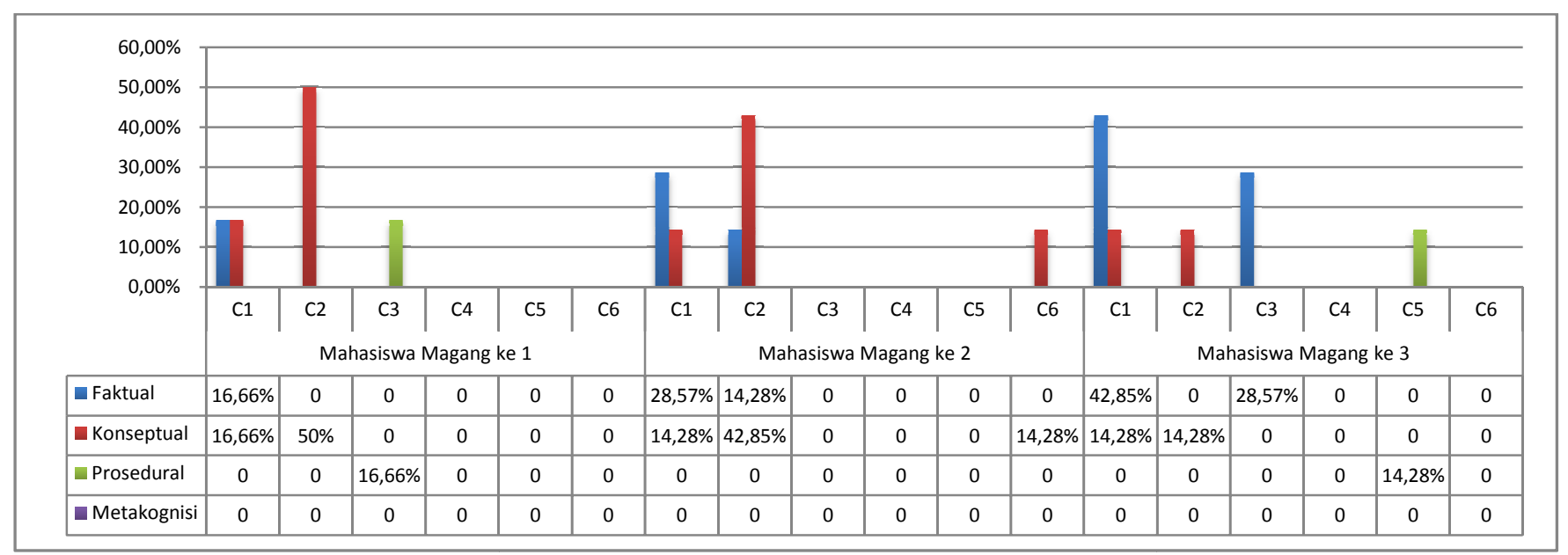

Gambar 1 Persentase Analisis Jenis Pertanyaan yang Diajukan Mahasiswa Magang di SMA Kota Sukabumi Berdasarkan Taksonomi Bloom Revisi pada Konsep Pencemaran Lingkungan

Pada gambar 1 didapat dari hasil analisis kemunculan persentase setiap mahasiswa magang pada aspek kognitif dan aspek pengetahuan menunjukan persentase paling tinggi pada C1 (menyebutkan) dan C2 (memahami), pada aspek kedua ini dimana mahasiswa dalam mengajukan pertanyaan kepada siswa banyak 
menggunakan aspek kognitif $\mathrm{C} 1$ dan $\mathrm{C} 2$ pada aspek pengetahuan faktual dan konseptual.

Hasil menunjukan sebanyak 21 pertanyaan yang diajukan mahasiswa magang dari 3 sekolah, dimana setiap satu mahasiswa magang ketika mengajar di SMA masing-masing mengajukan pertanyaan berjumlah yaitu 6,7 , dan 8 pertanyaan, lalu pertanyaan-pertanyaan tersebut dianalisis oleh peneliti dan dikelompokan berdasarkan aspek kognitif dan aspek pengetahuan taksonomi bloom revisi. Kemudian dari hasil analisis pengelompokkan berdasarkan jenjang kognitif dan jenjang pengetahuan taksonomi bloom revisi, dari ke 21 pertanyaan yang diajukan mahasiswa magang bahwa kemunculan pertanyaan mahasiswa magang dari tiga sekolah meliputi SMA N 2 Kota Suabumi, SMA N 3 Kota Sukabumi, dan SMA N 4 Kota Sukabumi pertanyaan yang paling banyak muncul yaitu pada jenjang kognitif C1 (mengetahui) dimensi faktual dan konseptual, kemudian C2 (memahami), walaupun ada kemunculan pertanyaan tingkat tinggi yaitu pada aspek C5 (mengevaluasi) dan C6 (mencipta) tetapi hasil persentase menunjukan pertanyaan tingkat rendah yang paling dominan digunakan ketiga mahasiswa magang dalam kegiatan mengajukan pertanyaan kepada siswa pada saat proses belajar mengajar. Namun dari setiap masing-masing mahasiswa magang yang mengajar di tiga sekolah kemunculan pertanyaan dominan pada jenjang C1 (mengetahui) dimensi faktual dan C2 (memahami) dimensi faktual dan konseptual. Sejalan dengan yang dikemukakan para ahli dan peneliti lain rata-rata guru dalam mengajukan pertanyaan tidak menanamkan pertanyaan tingkat tinggi.

Juhanda (2016) mengungkapkan bahwa hal ini bisa dikatakan wajar dikarenakan sebelum siswa diarahkan untuk memiliki keterampilan berpikir tingkat tinggi maka harus dimulai dengan menanamkan keterampilan berpikir tingkat rendah terlebih dahulu.Farihah(dalam Widodo, 2006) mengungkapkan bahwa sebagian besar pertanyaan yang diajukan guru maupun siswa dalam pembelajaran merupakan pertanyaan pada jenjang kognitif rendah (hafalan dan pemahaman). Dengan hal itu pertanyaan tingkat tinggipun perlu diterapkan oleh calon guru kepada siswa agar lebih menguasai dalam memahami materi yang diajarkan. 
Adapun dalam mengajukan pertanyaan tingkat rendah yang dilakukan oleh mahasiswa magang disekolah tidak hanya digunakan untuk meningkatkan pemahaman siswa dalam penguasaan materi yang dipelajari tetapi memberikan pertanyaan terhadap siswa digunakan juga sebagai alternatif dalam mengelola kelas.Hasil persentase kemunculan pertanyaan yang diajukan mahasiswa magang pada aspek kognitif $\mathrm{C} 1$ (mengetahui) dan aspek pengetahuan merupakan aspek yang tergolong muncul digunakan oleh mahasiswa magang ketika mengajukan pertanyaan kepada siswa. Pada aspek ini terbagi atas dimensi faktual dengan persentase mahasiswa magang ke 1 sebesar 16,66\% (kurang sekali) sedangkan dimensi konseptual sebesar 16,66\% (kurang sekali). Pada aspek kognitif C2 (memahami) merupakan aspek yang sering juga digunakan dalam mengajukan pertanyaan oleh mahasiswa magang, persentase pada aspek ini pada dimensi konseptual sebesar 50\% (kurang). Adapun pada aspek kognitif C3 (mengaplikasikan) dan dimensi prosedural persentase kemunculan sebesar $16,66 \%$.

Pada mahasiswa magang ke 2 persentase kemunculan aspek kognitif C1 (mengetahui) yaitu pada aspek pengetahuan faktual sebesar 28,57\% (kurang sekali),sedangkan aspek kognitif C1 pada aspek pengetahuan konseptualsebesar 14,28\%. Pada aspek kognitif C2 (memahami) pada aspek pengetahuan faktual sebesar 14,28\% (kurang sekali) sedangkan pada aspek C2 (memahami) aspek pengetahuan konseptual sebesar 42,85\% (kurang), pada aspek kognitif C6 (mencipta) sebesar 14,28\%.

Kemudian pada hasil analisis mahasiswa magang ke 3 kemunculan persentase pada setiap aspek kognitif dan aspek pengetahuan yaitu pada aspek kognitif C1 (mengetahui) aspek pengetahuan faktual sebesar 42,85\% (kurang), kemudian paspek kognitif C1 aspek pengetahuan konseptual sebesar 14,28\% (kurang sekali). Pada aspek kognitif C2 (memahami) aspek pengetahuan konseptual sebesar 14,28\% (kurang sekali), sedangkan aspek kognitif dan aspek pengetahuan persentase kemunculan pada pada aspek C3 (mengaplikasikan) aspek pengetahuan faktual sebesar $28,57 \%$ (kurang). Kemudian kemunculan pada aspek 
yang paling tinggi dari C3 (mengaplikasikan) dan C4 (menganalisis) yaitu C5 (mengevaluasi) persentase kemunculan sebesar 14,28\%.

keterampilan mahasiswa magang dalam mengajukan pertanyaan ketika melaksanakan kegiatan belajar mengajar dikelas cukup bervariasi. Hasil persentase jenis pertanyaan yang diajukan ketiga mahasiswa magang di masingmasing sekolah menunjukan dominasikemunculan jenis pertanyaan pada aspek kognitif $\mathrm{C} 1$ dan $\mathrm{C} 2$. Hal ini maka sangat jelas sekali bahwa kemampuan mahasiswa magang dalam mengajukan pertanyaan kepada siswa tergolong masuk dalam kategori aspek kognitif paling rendah yaitu sekedar menyebutkan, memahami, dan mengaplikasikan materi pembelajaran.Akan tetapi kemunculan pertanyaan tersebut memang diperlukan dalam pembelajaran sebelum menerapkan pertanyaan tingkat tinggi. Menurut Widodo (2006) menyatakan bahwa pertanyaan kognitif tingkat rendah merupakan dasar dari berpikir tingkat tinggi.Adanya kemunculan pertanyaan yang dominan tingkat rendah oleh mahasiswa magang ketika melaksakan kegiatan belajar mengajar dimana mahasiswa kurangnya kesiapan dalam menyusun pertanyaan. Dantidak hanya kurangnya persiapan, dalam kemunculan pertanyaan yang di dominasi aspek kognitif C1 dan C2 pada aspek pengetahuan faktual dan konseptual, pada aspek ini mahasiswa magang memberikan pertanyaan $\mathrm{C} 1$ dan $\mathrm{C} 2$ hanya memberikan pertanyaan terkait konsep yang ada dalam materi pencemaran lingkungan sehingga siswa hanya menyebutkan dan menjelaskan terkait yang ditanyakan oleh mahasiswa magang. Hasil temuan ini sejalan dengan penelitian yang dilakukan oleh Nasution (2002) yang menyatakan bahwa sebagian besar pertanyaan yang diajukan oleh guru merupakan pertanyaan ingatan $(\mathrm{C} 1)$ dan pemahaman $(\mathrm{C} 2)$.

Pada gambar 1 kemunculan pertanyaan yang paling sedikit yaitu pada jenjang pertanyaan tingkat tinggi yaitu jenjang kognitif C5 (mengevaluasi) dan C6 (mencipta), pada jenjang ini tergolong kurang sekali mahasiswa dalam memberikan pertanyaan kepada siswa. Padahal kemampuan berpikir tingkat tinggi itu penting. Rofiah (2013) mengemukakan bahwa pentingnya kemampuan berpikir tingkat tinggi adalah proses yang melibatkan aktivitas mental dalam usaha mengeksplorasi pengalaman yang kompleks, reflektif, dan kreatif yang 
dilakukan secara sadar untuk mencapai suatu tujuan, yaitu memperoleh pengetahuan yang meliputi tingkat berpikir analitis, evaluatif dan sintesis. Hal tersebut dapat dipengaruhi oleh kemampuan siswa dalam memahami materi yang diajarkan, dengan demikian mahasiswa magang tidak banyak memberikan pertanyaan-pertanyaan tingkat tinggi ketika melaksanakan kegiatan belajar mengajar dikelas. Pada dasarnya, hal tersebut siswa kurang pengarahan untuk memiliki keterampilan berpikir tingkat tinggi dan mahasiswa magangpun lemahnya memahami taksnomi bloom revisi sebagai acuan untuk membantu dalam memberikan pertanyaan ketika melaksanakan kegiatan belajar mengajar. Sejalan dengan penelitian yang dilakukan oleh Widodo (2006) tentang profil pertanyaan guru dan siswa dalam pembelajaran sains, yang menemukan bahwa pertanyaan yang diajukan guru merupakan pertanyaan pada tingkat kognitif rendah (hafalan dan pemahaman) serta lebih banyak mengajukan pertanyaan tertutup dari pada pertanyaan terbuka.Maka dari itu ketiga mahasiswa magang dalam memberikan pertanyaan tergolong kurang dalam memberikan pertanyaan tingkat tinggi yang dominan menggunakan pertanyaan tingkat rendah.

Kemudian hasil analisis dan hasil persentase aspek kognitif dan aspek pengetahuan yang tidak muncul dalam pertanyaan yaitu aspek kognitif $\mathrm{C} 4$ (menganalisis) dan aspek pengetahuan metakognitif. Pada gambar 1 dari masingmasing mahasiswa magang pada aspek kognitif C4 dan aspek pengetahuan metakognitif tidak adanya kemunculan pada aspek tersebut.Padahal aspek kognitif tingkat tinggidapat meningkatkan tingkat berpikir siswa, salah satunya yaitu aspek kognitif C4 (menganalisis) yang masuk dalam kategori aspek kognitif tingkat tinggi. Hal yang sama juga dikemukan oleh Shen dan Yodkhumle (2006) yang menyatakan bahwa untuk meningkatkan kemampuan berpikir kritis siswa, jenis pertanyaan yang harus diajukan dalam proses pembelajaran adalah pertanyaanpertanyaan kognitif tingkat tinggi. Sedikitnya pertanyaan yang diajukan mahasiswa magang menunjukkan bahwa kemunculan pertanyaan mahasiswa magang masih belum melatih siswa untuk mengembangkan kemampuan berpikirnya secara optimal, serta pertanyaan mahasiswa magang masih di kategorikan pertanyaan tingkat rendah dan mengindikasikan bahwa kemampuan 
bertanya ke tiga mahasiswa magang masih perlu ditingkatkan. Berdasarkan hasil observasi tersebut, mahasiswa magang masih sangat kurang dalam mengajukan pertanyaan tingkat tinggi. Hal ini menunjukkan bahwa guru lebih banyak mengajukan pertanyaan pada jenjang kognitif tingkat rendah daripada jenjang kognitif tingkat tinggi.

Dengan adanya penelitian ini yang menggunakan objek mahasiswa yang magang di sekolah harus lebih di ningkatkan lagi dalam menerapkan dan memahami aspek kognitif dan aspek pengetahuan taksonomi bloom revisi dalam proses kegiatan bertanya maupun dalam meningkatkan daya pikir siswa dalam poroses memahami materi yang di ajarkan.

\section{KESIMPULAN}

Jenis kemunculan pertanyaan yang diajukan mahasiswa magang berdasarkan aspek kognitif dan aspek pengetahuan taksonomi Bloom revisi pada materi pencemaran lingkan ditemukan dalam persentase yang hampir sama, ratarata kemunculan jenis pertanyaan jenjang kognitif tingkat rendah (lower order thinking) (C1, C2, dan (C3) tergolong dominan muncul dalam kegiatan mengajukan pertanyaan kepada siswa, sedangkan persentase kemunculan jenis pertanyaan berdasarkan jenjang kognitif tingkat tinggi (higher order thinking) C4sampai C6) tergolong kurang sekali muncul dalam mengajukan pertanyaan. Oleh karena itu, kemunculan jenis pertanyaan berbagai jenjang kognitif dan jenjang pengetahuan berdasarkan Taksonomi Bloom Revisi pada materi pencemaran lingkungan mahasiswa masih perlu untuk ditingkatkan, khususnya dalam memahami dan menerapkan pada saat proses belajar mengajar.

\section{DAFTAR PUSTAKA}

Ahmadi, A. (1977). Dasar-Dasar Praktek Mengajar. CV Toha Putra. Semarang. Arikunto. (2013). Prosedur penelitian (suatu pendekatan praktek). Jakarta: Rineka Cipta. 
Bloom, B.S.Et Al. (1956). The Taxonomy Of Educational Objectives The Classificaion Of Educationa Goal, Handbook I: Cognitive Domain. New York: David McKay.

Juhanda, I. A. (2014). Analisis Soal Jenjang Kognitif Taksonomi Bloom Revisi Pada Buku Sekolah Elektronik (BSE) Biologi SMA, 501, 61-66.

Mauigoa, L., dan Tekene. 2006. Enhancing Teachers' Questioning Skills to Improve Children's Learning and Thinking in Pacific Island Early Childhood Centres. Journal of Teachers' Work. 3(1): 12-23.

Nasution, S. (2009). Berbagai Pendekatan dalam Proses Belajar dan Mengajar. Jakarta: Bumi Aksara.

Rofiah, E, dkk. (2013). Penyusun Instrumen Tes Kemampuan Berpikir Tingkat Tinggi Fisika pada Siswa SMP. Jurnal pendidikan fisika, vol.1 No.2. 1721.[online]. Tersedia : http://download.portalgaruda.org/.php?.

Sarwono, Sarlito Wirawan. (1978). Perbedaan antara Pemimpin \& Aktifitas dalam Gerakan Protes Mahasiswa. UI-Press. Jakarta.

Shen. P dan B. Yodkhumlue. (2006). Teacher's Questioning and Student's Critical Thinking in College ELF Reading Classroom. The 8th international Postgraduated Research Colloqium: Interdiciplinary Approach of Enchancing Quality of Life IPRC Procceedings: 44-53.

Sofa. (2008). Keterampilan Bertanya Pada Siswa. [Online]. Tersedia: https://areknerut.wordpress.com/2012/12/30/978/

Widodo, A. (2006). Profil Pertanyaan Guru dan Siswa dalam Pembelajaran Sains Profil Pertanyaan Guru dan Siswa dalam Pembelajaran Sains. Jurnal Pendidikan Dan Pembelajaran, 4(2), 139-148. 